Gut, 1964, 5, 553

\title{
Comparison of jejunal mucosa in post-gastrectomy states, idiopathic steatorrhoea, and controls using the dissecting microscope and conventional histological methods
}

\author{
G. B. SCOTT, M. J. WILLIAMS, AND C. G. CLARK ${ }^{1}$ \\ From the Departments of Pathology, Materia Medica and Therapeutics, \\ and Surgery, University of Aberdeen, Aberdeen Royal Infirmary
}

EDITORIAL SYNOPSIS Jejunal biopsies from 24 patients with various post-gastrectomy states were compared with those from control patients and patients with idiopathic steatorrhoea. Minor histological changes, such as shortening and thickening of the villi, were frequently encountered in the control subjects, but the dissecting microscope showed that these were related to variations in villous shape. Similar changes in the villi were found in the post-gastrectomy patients, leaf-shaped villi and ridge formation being more common than was thought.

Impaired absorption of various substances is not uncommon following partial gastrectomy. Interest in the relationship between changes in the jejunal mucosa and defective absorption was stimulated by the observations of Paulley (1954) and Shiner and Doniach (1960) who showed specific mucosal changes in patients with idiopathic steatorrhoea. Several groups of workers have studied this aspect of postgastrectomy malabsorptive states and two views have emerged on the structure of the upper small intestinal mucosa in such cases.

Paulley, Fairweather, and Leeming (1957) and Joske and Blackwell (1959) found changes in the jejunal mucosa similar to those found in idiopathic steatorrhoea, and suggested that these patients had a latent defect in small bowel function made manifest by partial gastrectomy.

Others have been unable to confirm these suggestions in studies of the jejunal mucosa in a combined total of 98 patients (Baird and Dodge, 1957; Lees and Grandjean, 1958; Rubin, Brandborg, Phelps, and Taylor, 1960; Deller, Richards, and Witts, 1962; Girdwood, 1962; Jones, Cox, Cooke, Williams, Meynell, and Stammers, 1962). Although no gross changes in villous structure were found, minor changes in mucosal histological structure were sometimes noted, with slight shortening and

'Present address: Professorial Surgical Unit, The General Infimary, Leeds. thickening of villi (Baird and Dodge, 1957; Deller et al., 1962) or inflammatory cell infiltration (Deller, 1962; Jones et al., 1962). These changes were considered of doubtful significance and no correlation was found between alterations in the structure of the jejunal mucosa and impaired absorption after partial gastrectomy.

In all these reports, jejunal biopsies were studied by conventional histological techniques. Although gross changes in villous structure are readily recognizable by microscopic examination, minor changes are more difficult to interpret, as similar appearances are produced when sections are cut slightly tangentially (Brandborg, Rubin, and Quinton, 1959). It has recently been shown that a clearer view of the villous pattern is obtained when samples of jejunal mucosa are examined under the dissecting microscope (Holmes, Hourihane, and Booth, 1961 a and b) and we have used this technique, in addition to conventional histological methods, to study the jejunal mucosa in patients presenting with various symptoms following partial gastrectomy.

The biopsy appearances in this group of patients have been compared with those from patients with idiopathic steatorrhoea and from a group of control cases, and the value of examination of the specimen with the dissecting microscope in detecting changes in villous structure has been assessed. 
MATERIAL AND METHODS

Jejunal biopsies from three groups of patients have been studied.

1 CONTROL GROUP (15 CASES) The final diagnosis and age of the patients are shown in Table I. All were being investigated for abdominal symptoms but in no case was there evidence of peptic ulceration or of malabsorption and none had had previous gastric surgery. Jejunal biopsies were taken from the proximal jejunum at operation in nine cases and with the Crosby capsule in six (Crosby and Kugler, 1957).

2 IDIOPATHIC STEATORRHOEA GROUP (EIGHT CASES) These patients all presented the classical features of idiopathic steatorrhoea (Cooke, Peeney, and Hawkins, 1953) and all had demonstrable steatorrhoea in addition to other absorptive defects. Two gave a history of coeliac disease in childhood. Jejunal biopsies were taken with the Crosby capsule before any treatment had been given.

3 POST-GaStRectomy group ( 24 CASES) These patients had had partial gastrectomies of the Polya type and presented subsequently with varying complaints. Biopsies were taken from the efferent loop of the jejunum at a point 6 in. distal to the stoma, either at the time of further operation (six cases) or with the Crosby capsule (18 cases). Other investigations were performed as appropriate. Biochemical and haematological estimations were by standard methods. Faecal fat excretion was measured over two or three consecutive three-day periods, by the method of Kamer, Huinink, and Weyers (1949). The xylose excretion test was performed as decribed by Fowler and Cooke (1960). Specific tests of iron and folic acid absorption were not performed and evidence of deficiency of these substances was only considered in the presence of the typical haematological changes and when a satisfactory therapeutic response to their administration had been shown, In the assessment of bone disease, detailed investigations were carried out as reported elsewhere (Mitchell, Dawson, Clark, and Crooks, 1964).

The jejunal biopsy specimens were first examined under the dissecting microscope after prior fixation in formol saline. The appearances were classified as follows, the descriptive terms used being those introduced by Holmes et al. (1961a and b). For convenience we have applied a numerical type for the different appearances.

Finger shaped villi predominant ...... Type I (Fig. 1)

Leaf-shaped villi predominant ........ Type II (Fig. 2)

Leaf-shaped villi with distinct ridge

formation .................... Type IIa (Fig. 2a)

'Convoluted' mucosa ............... Type III (Fig. 3)

'Flat' mucosa .... $\quad . . \ldots \ldots \ldots \ldots$. Type IV (Fig. 4)

The first two types are considered as normal variants (Holmes et al., 1961b) but we have classified them separately according to the predominant villous form present. In some instances, leaf-shaped villi were found alternating, in the same specimen, with areas of distinct ridge formation and such appearances have been classified separately as type IIa. These appearances were quite different to those found in the next type, the 'convoluted' mucosal, as unlike the latter, the ridges found were tall and narrow and areas with distinct villi were always found in the same specimen. The appearances of the 'convoluted' and 'flat' mucosae which we have termed type III and type IV were as described by Holmes et al. (1961a and b) and the changes were always uniform in the individual specimen. As noted by Holmes et al. (1961a and b), the surface of the convoluted and flat mucosae is often divided by shallow grooves into round or hexagonal areas giving a 'mosaic' pattern but such appearances have not been classified separately.

In the histological study, sections were prepared in the conventional manner, stained with haematoxylin and eosin and examined by one of us (G.B.S.). The slides were numbered and studied in random fashion without prior knowledge of the dissecting microscope appearances or from which group of cases the sections came, allowing a comparison to be made between the two methods of examination in detecting changes in villous structure. The villous pattern was noted and villous atrophy, if present, was classified according to the criteria of Shiner and Doniach (1960). Minor alterations in the appearance of individual villi, such as slight reduction in height or thickening, were recorded, and an attempt was made to recognize leaf-shaped villi in the histological sections. Congestion and inflammatory cell infiltration were also recorded and if the latter was present, then the cell types involved and their distribution were noted.

\section{RESULTS}

1 CONTROL GROUP The findings are shown in Table I. Finger-shaped villi (type I) were seen with the dissecting microscope in 10 cases, although in four of these small numbers of leaf-shaped villi (type ll) were also present. Leaf-shaped villi alone were present in two cases, and in one case equal numbers of these two villous forms were seen. In the remaining two cases, the villi were mainly leafshaped but areas of distinct ridge formation (type IIa) were identified. Both these specimens also contained numbers of finger-shaped villi.

Histologically, the gross villous pattern was regarded as normal except in one case (C 10) where the appearances were considered to approach those found in partial villous atrophy. The dissecting microscope, however, revealed only leaf-shaped villi in this case.

Minor histological changes in villous appearances were noted in 10 of the 15 cases. Reduction in villous height was noted in nine cases with slight thickening of villi in two of these and thickening alone in one case. Comparison of these findings with the appearances under the dissecting microscope showed that leaf-shaped villi were present in six of the 10 cases 
TABLE I

CONTROL GROUP

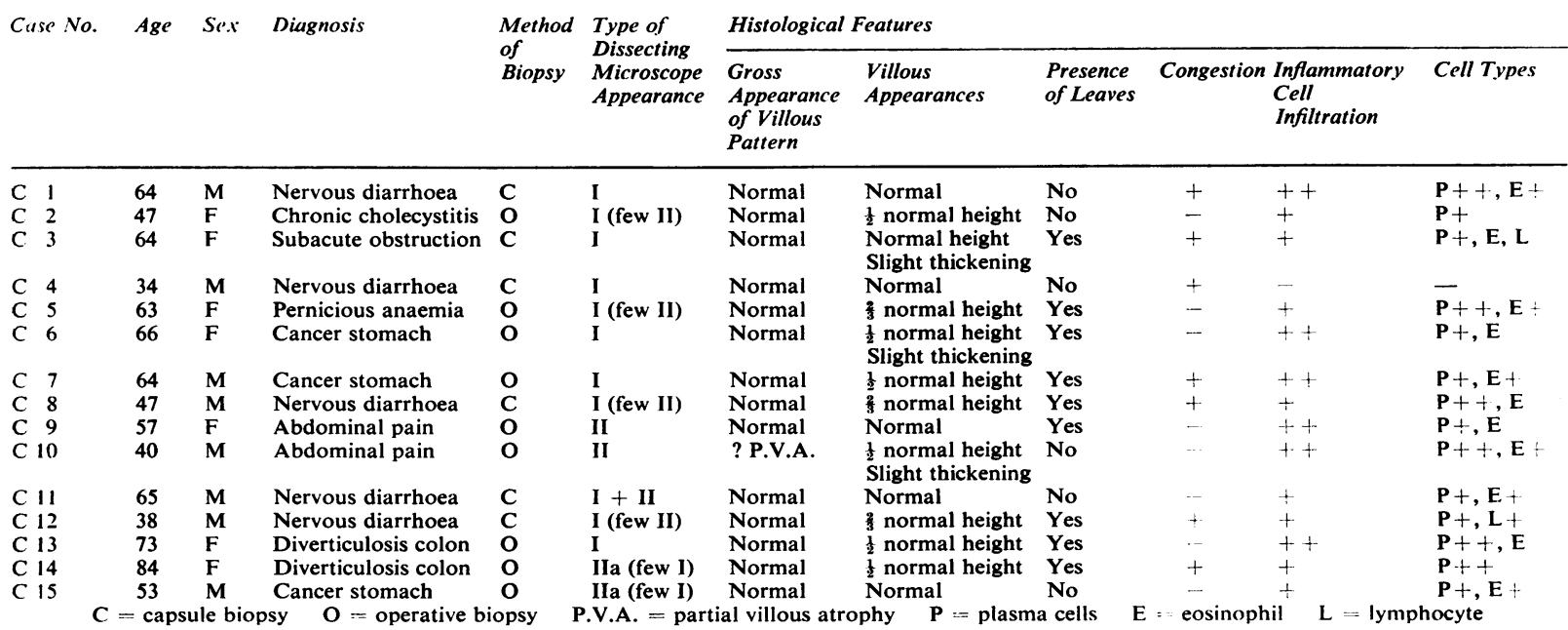

TABLE II

IDIOPATHIC STEATORRHOEA GROUP

Case No. Age Se.X $\quad \begin{aligned} & \text { Type of Dissecting } \\ & \text { Microscope } \\ & \text { Appearance }\end{aligned}$

Histological Features

\begin{tabular}{|c|c|c|c|}
\hline $\begin{array}{l}\text { Gross Appearances } \\
\text { of Villous Pattern }\end{array}$ & Congestion & $\begin{array}{l}\text { Inflammatory Cell } \\
\text { Infiltration }\end{array}$ & Type of Cells \\
\hline
\end{tabular}

I.S. $1^{1}$

I.S. 2

I.S. 3

I.S. 4

I.S. 5

I.S. $6^{1}$

I.S. 7

I.S. 8

$\begin{array}{lll}20 & \text { M } & \text { IV } \\ 50 & \text { M } & \text { III } \\ 62 & \text { M } & \text { III } \\ 49 & \text { M } & \text { IV } \\ 76 & \text { F } & \text { III } \\ 20 & \text { M } & \text { IV } \\ 67 & \text { M } & \text { III } \\ 53 & \text { F } & \text { III } \\ \text { S.V.A. } & =\text { subtotal villous atrophy }\end{array}$

'Previous coeliac disease

having some villous abnormality, although in only two of these was this the main villous form. In the two cases with definite ridge formation (C 14 and 15), histology showed normal villous appearances in one (C 15) and villi reduced to half normal height in the other (C 14).

A special attempt was made to recognize leafshaped villi histologically and comparison with the dissecting microscope findings shows that they were recognized correctly in five of nine cases but wrongly thought to be present in four.

Congestion was noted in seven cases. Correlation of this with the method of obtaining the biopsy showed that it was present in five of six capsule biopsies and in only two of nine operative biopsies. Cell infiltration was almost uniform, being absent in one case only. It was marked in six cases and always involved the lamina propria uniformly. Plasma cells were predominant though eosinophils were also frequently seen. Excessive numbers of lymphocytes were noted in two cases.

2 IDIOPATHIC STEATORRHOEA GROUP The dissecting microscope appearances in all cases were strikingly abnormal, no true villous structures being identified (Table II). Five cases showed a 'convoluted' mucosa (type III) and three a 'flat' mucosa (type IV).

Both cases with a prior history of coeliac disease (I.S. 1 and 6) showed a flat mucosa. There was, however, no apparent difference in the clinical picture related to the two types of mucosa and both may be seen in the same patient. Thus one patient (I.S. 7) showed a 'convoluted' mucosa, but a repeat biopsy, not included here, taken two weeks later without specific treatment having been given showed a 'flat' mucosa. Histologically, five cases showed partial villous atrophy and three subtotal villous atrophy. Comparison with the dissecting 

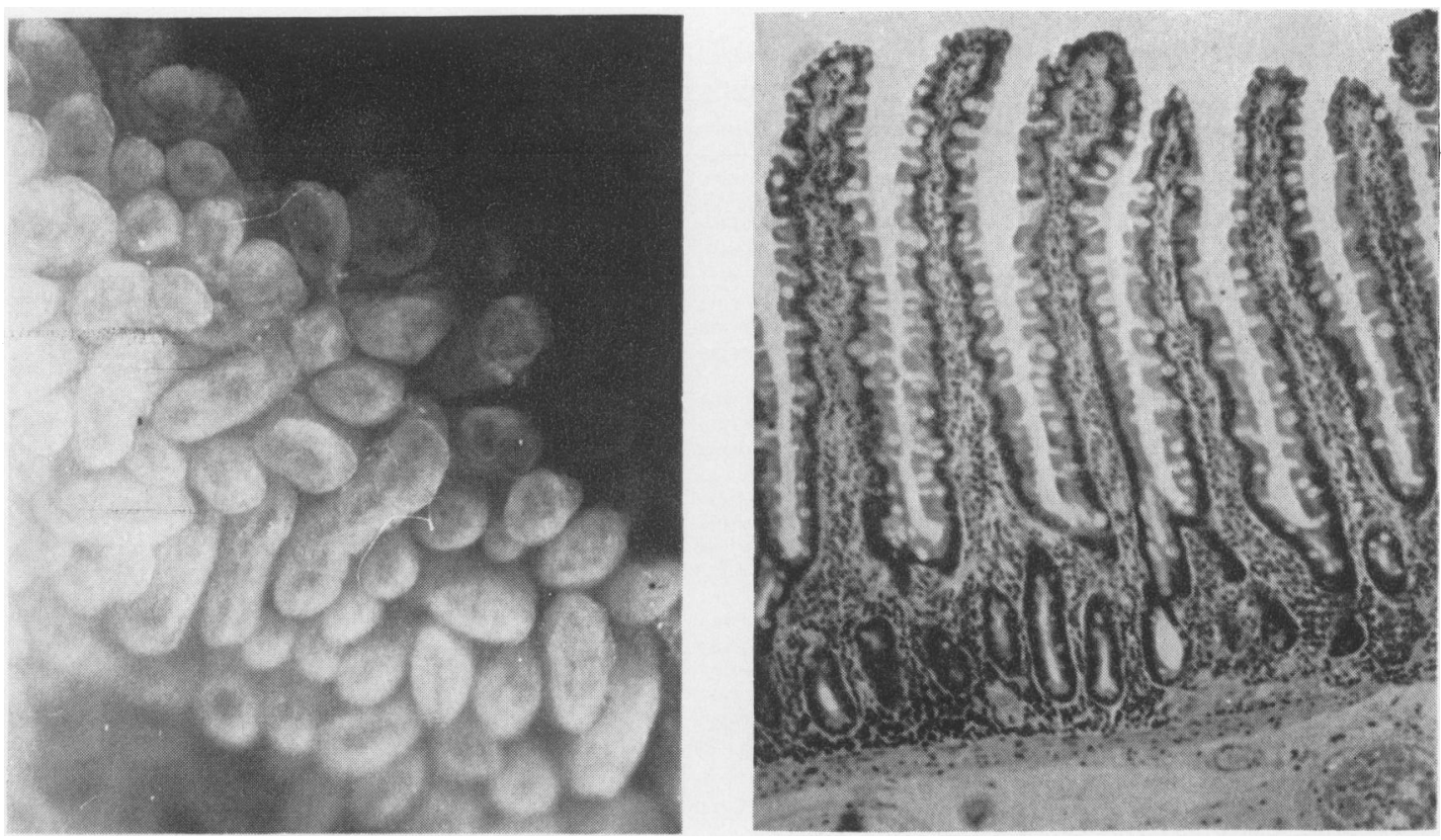

FIG. 1. Left. Dissecting microscope appearance of mucosa composed mainly of finger-shaped villi, but including several leaf-shaped forms $(\times 80)$.

Right. Histological appearance of finger-shaped villi (haematoxylin and eosin $\times 100$ ).
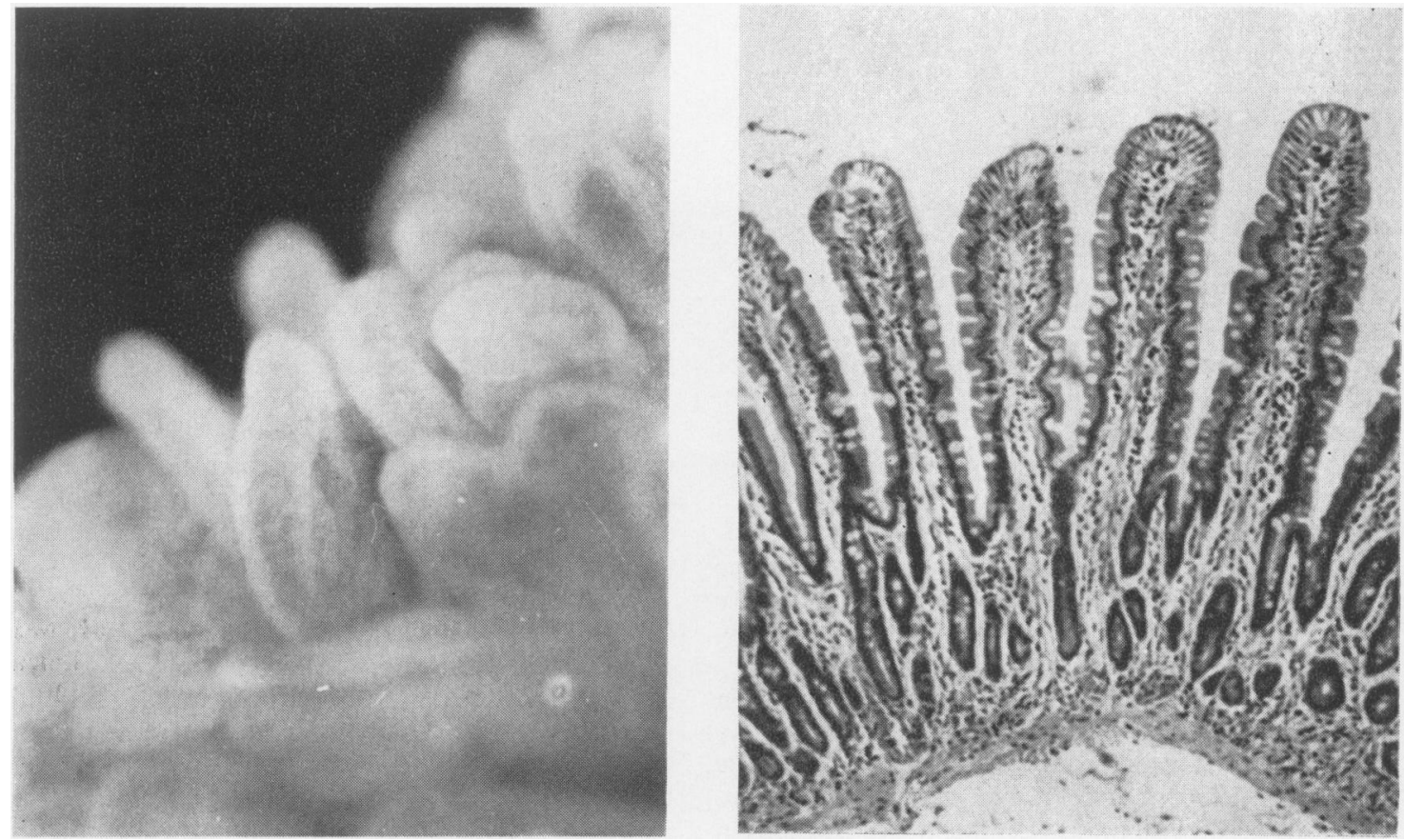

FIG. 2. Left. Leaf-shaped villi, showing typical broad flattened appearance $(\times 120)$.

Right. Histological appearance of leaf-shaped villi, which are almost identical with finger villi (haematoxylin and eosin 100). 

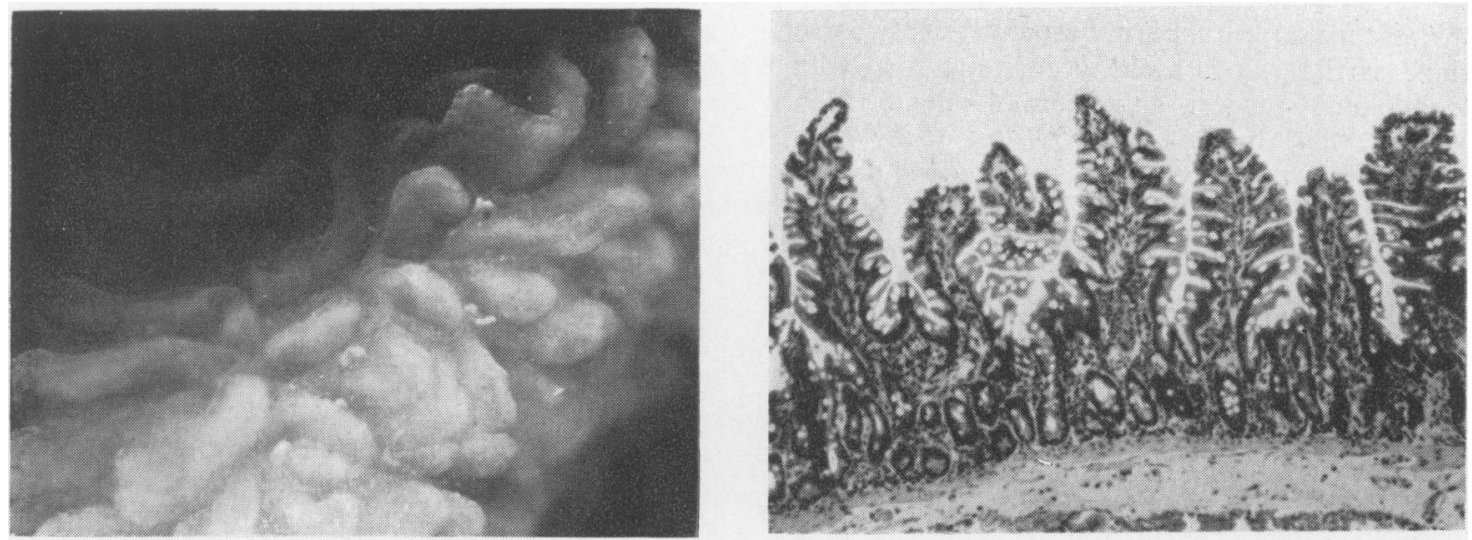

FIG. 2a. Left. Leaf-shaped villi with several ridges $(\times 60)$.

Right. Histologically the villi are shortened and some appear broader than normal (haematoxylin and eosin $\times 75$ ).
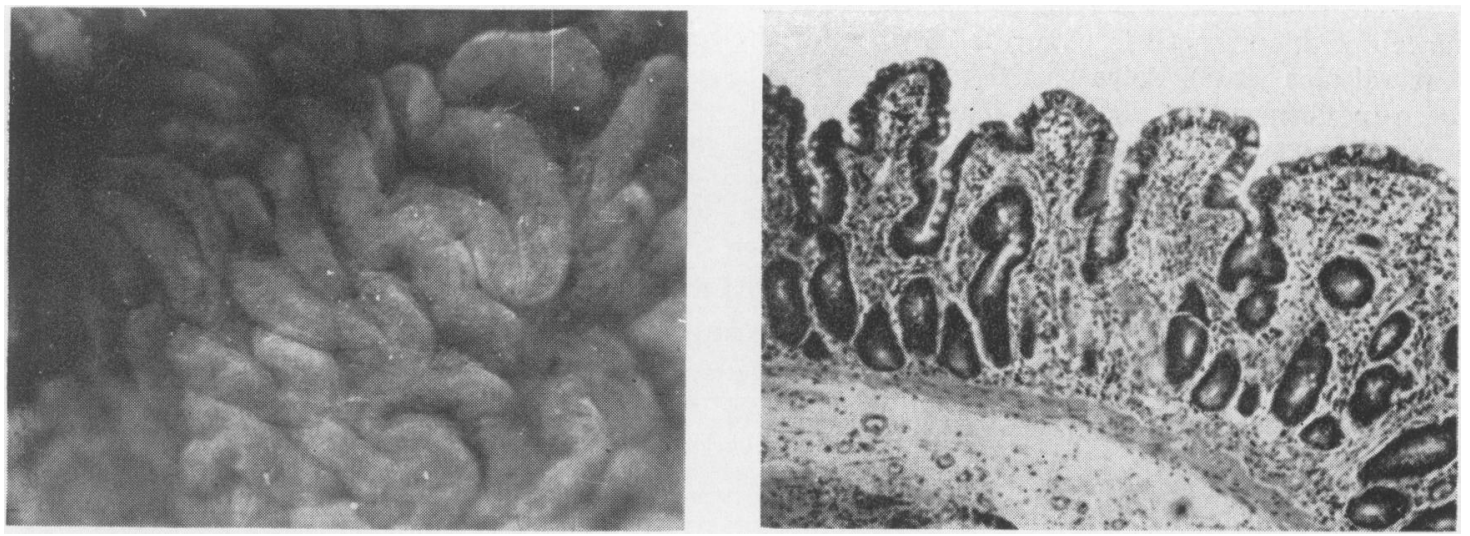

FIG. 3. Left. Convoluted mucosa.

Right. Histologically no true villi, mucosa reduced in height, often described as partial villous atrophy (haematoxylin and eosin $\times$ 75).
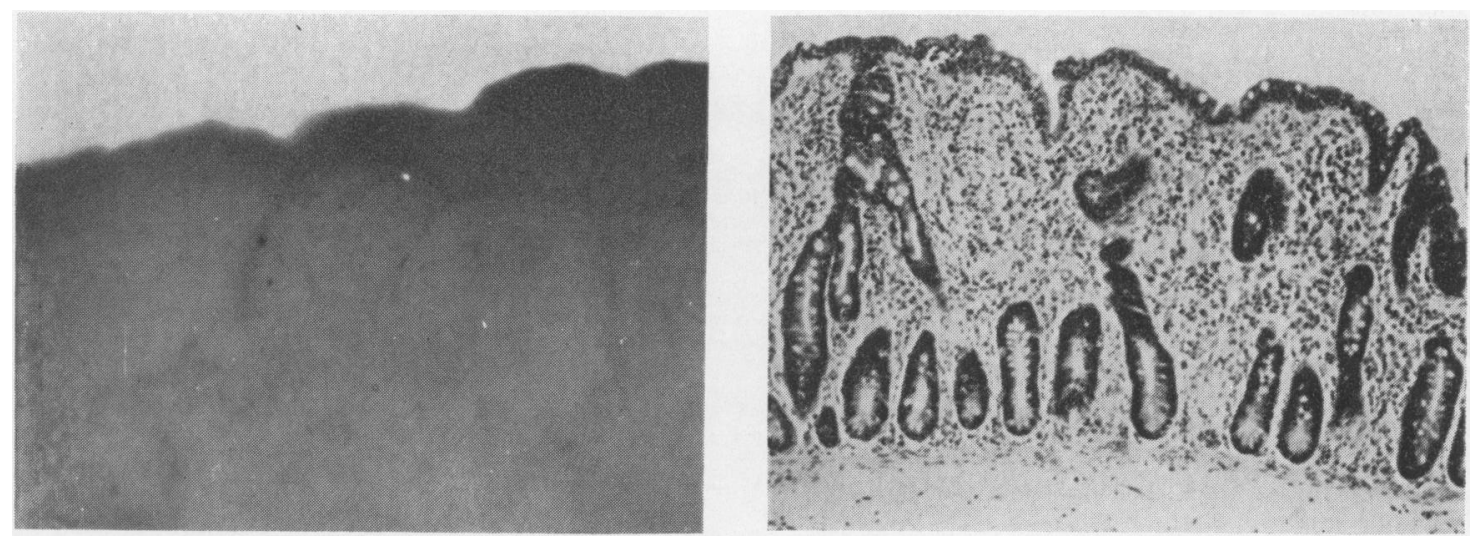

FIG. 4. Left. The amorphous appearance of the flat mucosa.

Right. Histologically, complete absence of villi, an increase in the glandular layer, and diffuse infiltration with chronic inflammatory cells (haematoxylin and eosin $\times 75$ ). 
microscope appearances shows an absolute correlation, partial villous atrophy corresponding with a 'convoluted' mucosa and subtotal villous atrophy with a 'flat' mucosa. Histological study of the former, however, does not reveal the true nature of the alteration because no villous structures are recognized with the dissecting microscope, the appearances of short stumpy villi being produced by vertical section through the convolutions.

Congestion was present in six cases. All biopsies in this group were taken with the Crosby capsule. Inflammatory cell infiltration was marked in all cases. Plasma cells were always noted in excess and increased numbers of eosinophils in four. Lymphocytes were only notable in one case.

3 post-Gastrectomy group Clinical details and pathological findings are shown in Table III. There were 22 males and two females and the interval since operation ranged from two to 23 years (mean interval nine years). Polya partial gastrectomy had been performed in all cases. The diagnosis at operation was duodenal ulcer in 16 cases, gastric ulcer in five cases, and combined gastric and duodenal ulcers in two cases. In one case (P.G. 19) operation was performed for symptons suggestive of pyloric obstruction but no lesion was found in the excised portion of stomach.

The pathological findings in the jejunal mucosa are shown in Table III. Finger-shaped villi were predominant in six cases but some 'leaves' were present in three of these. Leaf-shaped villi were predominant in nine cases with occasional fingershaped villi in four of these. In a further three cases there were equal numbers of these two villous types. In four of the cases with leaf-shaped villi small numbers of very broad leaves were seen suggesting early ridge formation. In five other cases, definite ridge formation was seen alternating with leafshaped villi. In four, the ridges were tall and narrow but in one (P.G. 9), were so low as to suggest a transition towards a convoluted mucosa although areas with distinct leaf-shaped villi were still present. No true convoluted mucosa (type III) was encountered but one case (P.G. 19) showed a typical flat mucosa (type IV).

The gross villous pattern was considered normal histologically in 22 cases. One case (P.G. 19) showed subtotal villous atrophy, and one (P.G. 20) partial villous atrophy. The dissecting microscope showed a

TABLE III

POST-GASTRECTOMY GROUP

$\begin{array}{lll}\text { Case Age Sex } & \begin{array}{l}\text { Interval } \\ \text { Since } \\ \text { Operation } \\ (y r .)\end{array} & \begin{array}{l}\text { Reason for } \\ \text { Operation }\end{array} \\ & \end{array}$

P.G. 144

P.G. 144

P.G. 247

P.G. 361

P.G. 460

P.G. 5 37

P.G. 650

P.G. 737

P.G. 872

P.G. 946

P.G. 1045

P.G. 1160

P.G. 1248

P.G. 1361

P.G. 1458

P.G. $15 \quad 48$

P.G. 1651

P.G. 1762

P.G. 1856

P.G. 1950

P.G. 2059

P.G. 2169

P.G. 2257

P.G. 2346

P.G. 2461

Duodenal ulcer
Duodenal ulcer
Duodenal ulcer
Duodenal ulcer
Duodenal ulcer
Duodenal ulcer
Duodenal ulcer
Duodenal ulcer
Duodenal ulcer
Duodenal ulcer
Gastric ulcer
Duodenal ulcer
Duodenal ulcer
Duodenal and
gastric ulcers
Duodenal ulcer
Duodenal ulcer
Duodenal and
gastric ulcers
Duodenal ulcer
Nil
Gastric ulcer
Gastric ulcer
Duodenal ulcer
Gastric ulcer
Duodenal ulcer
biopsy O $=$ operat

$\begin{array}{lll}\text { C } & \text { IIa } & \text { Normal } \\ \text { O } & \text { II } & \text { Normal } \\ \text { C } & \text { II (few I) } & \text { Normal } \\ \text { O } & \text { IIa } & \text { Normal } \\ \text { C } & \text { I } & \text { Normal } \\ \text { C } & \text { I (few II) } & \text { Normal }\end{array}$

C I Normal

C II (few I) Normal

$\begin{array}{lll}\text { C } & \text { IIa-III } & \text { Normal } \\ \text { O } & \text { I } & \text { Normal }\end{array}$

O II Normal

o

C I $\quad$ I II

I (few II)

Normal

Normal

C 1 Normal

C $\quad$ II + II

C II

C I + II

C IV

C II (few I)

Normal

Normal

Normal

S.V.A.

P.V.A.

C I (few II)

Normal

M $\quad 18$

M 11

M 2

C $=$ capsule biopsy
O II (few I) Normal $\begin{array}{ll}\mathbf{P}=\text { plasma cells } & \text { S.V.A. }=\text { subtotal } \\ \mathrm{E}=\text { eosinophil }\end{array}$

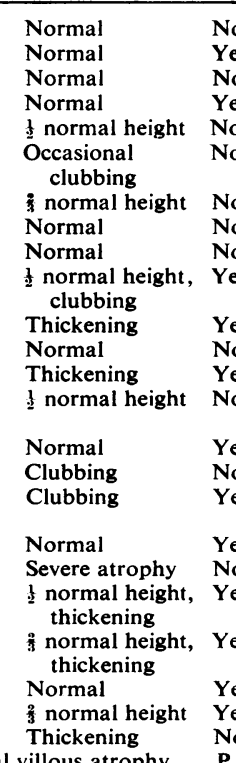

$\mathrm{L}=$ lymphocyte 
flat mucosa in the former but only leaf-shaped villi in the latter.

Some histological change in the villi was noted in 13 cases excluding the above two, with reduction in height in seven and thickening or clubbing of the villi in eight, both changes being present in two. In these 13 cases, leaf-shaped villi were seen with the dissecting microscope in 10 cases.

The dissecting microscope showed 'leaf-shaped' villi in 20 cases. A special attempt was made to identify such villi in the histological preparations without knowledge of the previous findings but they were only recognized correctly in 11 cases (Fig. 2). Congestion was found in 13 cases, and was present in 10 of 17 capsule biopsies and in three of the seven operative biopsies. Cell infiltration was noted in all cases, but only marked in six. The cell types involved did not differ from the controls.

\section{CORRELATION OF CLINICAL AND PATHOLOGICAL FINDINGS}

Evidence of disturbed nutrition and defective absorption was frequent in the post-gastrectomy patients (Table IV). Anaemia ( $\mathrm{Hb}<11.5 \mathrm{~g} . / 100 \mathrm{ml}$.) was present in 12 cases with evidence of iron deficiency in all instances. The presence or absence of anaemia bore no relationship to the state of the jejunal mucosa. Specific tests of vitamin $B_{12}$ absorption were not performed but there was no clinical evidence of $\mathrm{B}_{\mathbf{3 2}}$ deficiency in any of the patients. Folic acid deficiency was present, however, in two cases (P.G. 19 and 20). One (P.G. 19) showed a flat mucosa but only leaf-shaped villi were noted in the other (P.G. 20). Faecal fat estimations were performed in 13 cases. Five showed steatorrhoea (faecal fat $>5$ g. per day) and eight normal fat excretion. Again. no correlation was found with the state of the jejunal mucosa and steatorrhoea was seen in patients with only 'finger'-shaped (P.G. 6) or 'leaf'-shaped villi (P.G. 11 and 15).

The xylose excretion test was carried out in 19 patients with abnormal results in 10 (five-hour xylose excretion $<4.5$ g.). Comparison with the pathological findings showed that 'finger'- and 'leaf'-shaped villi or 'ridged' mucosae were associated with both normal and abnormal results. Metabolic bone disease was recognized in seven patients. Further details of these patients and the methods of investigation are reported elsewhere (Mitchell et al. 1964). The jejunal mucosa in all these patients contained 'leaf'-shaped villi as the sole villous type in five but with equal numbers of 'finger'-shaped villi in two. Bone disease was not identified in any patient with entirely 'finger'-shaped villi.

Inflammatory cell infiltration was present in all 24 cases but was only marked in six. Four patients presented with stomal ulceration but in only one of these (P.G. 10) was inflammatory cell infiltration notable.

TABLE IV

LABORATORY FINDINGS IN POST-GASTRECTOMY GROUP

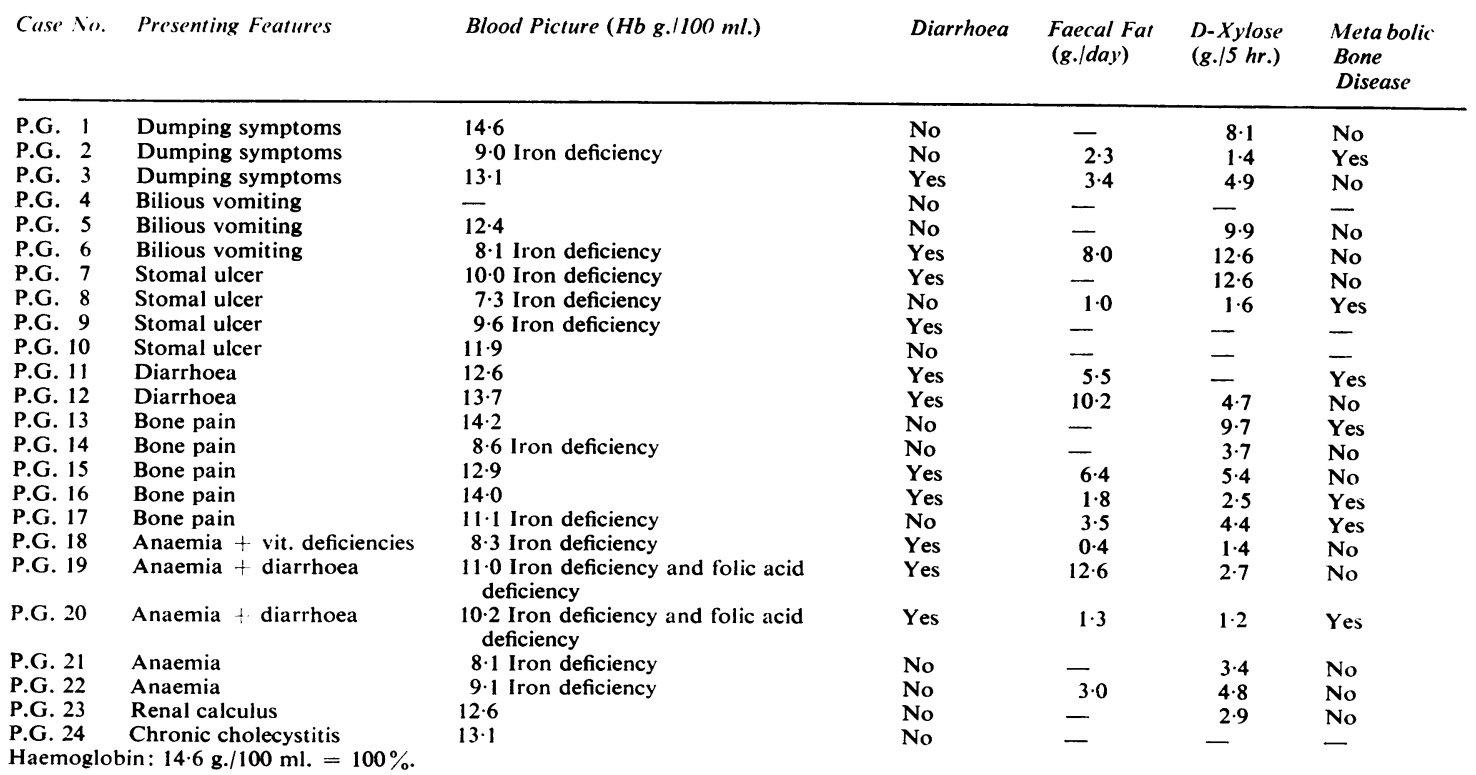


DISCUSSION

The villi of the human small intestine have been described as predominantly slender, finger-like processes, and leaf-shaped villi, although occurring in the duodenum, were thought to be rare in the jejunum (Shiner and Doniach, 1960). These observations were based entirely on histological studies, but we have shown that only a small proportion of leaf-shaped villi can be recognized by this method, depending on the plane of section through the leaf. This disadvantage is inherent in the two-dimensional view provided by conventional histology and can be overcome by examining the villous surface of the biopsy specimen under low magnification with a dissecting microscope as originally suggested by Rubin et al. (1960) and applied by Ralston, Wood, and Hughes (1960) and Holmes et al. (1961a and b).

Using this technique we have confirmed that leafshaped villi are not uncommon in jejunal mucosa from control patients (Holmes et al., 1961a and b) being seen in nine of our 15 cases, although in only three was this the main villous type present. Ridge formation among such leaf-shaped villi may also occur. As the majority of our control cases had abdominal symptoms, the significance of these changes is uncertain but the leaf-shaped villus may represent the earliest stage of mucosal abnormality (Booth, Stewart, Holmes, and Brackenbury, 1962). The appearances in a number of our cases suggest that these villous forms may arise by fusion of adjacent finger-shaped villi and that fusion of leafshaped villi may in turn give ridge formation.

Minor histological changes were frequently encountered in the control cases, individual villi appearing thickened or shortened and, where marked, these appearances may suggest partial villous atrophy. In many instances, these minor changes can be related to the presence of leaf-shaped villi or ridges, but tangential sectioning can produce similar appearances (Brandborg et al., 1959). These interpretative difficulties are overcome by prior study of the villous pattern with the dissecting microscope.

In the idiopathic steatorrhoea group, the histological findings were in agreement with previous observations (Butterworth and Perez-Santiago, 1958; Fone, Meynell, Harris, Cooke, Brewer, and Cox, 1960; Girdwood, Delamore and Wynn Williams, 1961 ; Rubin et al., 1960; Shiner and Doniach, 1960), the jejunal mucosa showing either partial or subtotal villous atrophy. The appearances under the dissecting microscope were also characteristic, either a convoluted or a flat mucosa being found. These appearances have been fully described (Holmes, et al. $1961 \mathrm{a}$ and b) and appear to be a constant finding in idiopathic steatorrhoea (Booth et al., 1962). Close agreement was found using the two techniques of examination, partial and subtotal villous atrophy corresponding with the convoluted and flat appearance respectively, but the dissecting microscope gives a much clearer view of the mucosal abnormality. In addition it avoids the error of wrongly diagnosing partial villous atrophy in a 'normal' mucosa and of interpreting a 'convoluted' mucosa as 'normal'. Indeed, it is possible that some of the reported cases of idiopathic steatorrhoea with histologically 'normal' jejunal biopsies (Fone et al., 1960; Girdwood et al., 1961) would show an abnormal appearance examined under the dissecting microscope.

In the post-gastrectomy group, the villous types seen with the dissecting microscope were, with one exception, similar to those found in the control cases. The relative incidence of different villous types, however, differed significantly from that found in the control group. Thus leaf-shaped villi and ridge formation were more frequent, being present in $70 \%$ of this group compared with $33 \%$ of the controls. Minor histological changes in villous structure were common with shortening or thickening of villi. Similar changes have been noted previously (Baird and Dodge, 1957; Deller et al., 1962) but they were no more frequent in our postgastrectomy group than in the controls and were probably related to the presence of leaf-shaped villi. Congestion was more frequently noted in biopsies taken with the Crosby capsule than in operative biopsies and is probably due to suction exerted when taking the biopsy.

Inflammatory cell infiltration has been recorded (Deller, 1962; Jones et al., 1962) and may be responsible for hypoalbuminaemia and hyperglobulinaemia (Jones et al., 1962). Cell infiltration was no more marked in our post-gastrectomy cases than in the control cases, apart from the patient (P.G. 19) with the flat mucosa when the intensity of infiltration was of the degree found in idiopathic steatorrhoea. No increase in infiltration was noted in the presence of stomal ulceration.

No correlation has previously been noted between changes in the jejunal mucosa and the occurrence of impaired absorption of fat, iron, or vitamin $\mathbf{B}_{12}$ after partial gastrectomy (Badenoch, Evans, Richards, and Witts, 1955; Baird and Dodge, 1957; Deller et al., 1962; Deller, 1962; Jones et al., 1962). Similarly, no correlation was noted in our cases when analysed according to the main villous type present. Thus steatorrhoea, anaemia, or an abnormal xylose test were seen with a normal villous pattern whilst conversely, an 'abnormal' villous pattern could be unassociated with these findings. It is of interest that metabolic bone disease was never encountered in a patient with a 
strictly 'normal' mucosa. Leaf-shaped villi were present in all seven cases with bone disease, as the sole villous type in five, and with equal numbers of 'fingers' in two.

Only occasional cases of osteomalacia as a complication of gastrectomy have been reported (Cameron, Bensley, English, and Wood, 1955; Pyrah and Smith, 1956; Baird and Oleesky, 1957; Ellman and Irwin, 1959; Melick and Benson, 1959) but it is now known to be more frequent than hitherto recognized (Clark, Crooks, Dawson, and Mitchell, 1964; Harvald, Krogsgaard, and Lous, 1962). This complication has been related to bypassing of the duodenum (Hillemand, Mialaret, and Boutelier, 1960) where an active transport system for calcium absorption is sited (Schacter and Rosen, 1959). Changes in villous structure in the jejunum may, however, be a further factor involved but larger numbers of cases will need to be studied and more information is required on the physiological or pathological significance of leaf-shaped and ridged villi. Their presence must inevitably reduce the absorptive surface area and furthermore their functional efficiency is considered to be less than that of finger-shaped villi (Verzár and McDougall, 1936).

The significance of the increased incidence of leaf-shaped villi and 'ridges' in our post-gastrectomy group is uncertain. We have noted similar findings after gastroenterostomy (Scott, Williams, and Clark, 1963) and comparable histological changes have been reported after gastric bypass procedures (Callender, Witts, Allison, and Gunning, 1961) and after total gastrectomy (Paulson and Harvey, 1954) implying that mechanical factors may be responsible (Deller, 1962).

A distinctly abnormal mucosa was found in only one patient in the group (P.G. 19), the dissecting microscope showing a flat mucosa with the appearances of subtotal villous atrophy histologically. Occasional cases have been encountered by others (Shiner and Doniach, 1960; Ashworth and Chears, 1962) and the cases reported by Paulley et al. (1957) and Joske and Blackwell (1959) were possibly similar. This degree of pathological change is believed to be specific for idiopathic steatorrhoea (Rubin et al., 1960, Yardley, Bayless, Norton, and Hendrix, 1962) and gastrectomized patients with this type of jejunal mucosa presumably have latent idiopathic steatorrhoea made overt by operation (Paulley et al., 1957; Joske and Blackwell, 1959). Although clearly a rare cause of malabsorption following gastrectomy, the recognition of these cases is of some importance as the presence of a flat mucosa implies the likelihood of therapeutic response to a gluten-free diet (Yardley et al., 1962). The clinical picture accompanying this mucosal change in the post-gastrectomy patient is not specific. Malabsorption is likely to be marked but can be equally severe in patients with a normal mucosa, and jejunal biopsy is the only method, at present available, for the detection of such cases.

\section{SUMMARY}

Jejunal biopsies from 24 patients with various postgastrectomy states have been examined and compared with biopsies from control patients and patients with idiopathic steatorrhoea. The specimens were examined histologically and the villous surface studied with a dissecting microscope independently, allowing a comparison to be made between the two methods of examination.

Minor histological changes, such as shortening and thickening of villi, were frequently encountered in the control subjects but the dissecting microscope showed that these were related to variation in villous shape. Although the villi of the jejunum are most commonly finger-shaped, leaf-shaped villi and ridge formation were frequent, being present in $33 \%$ of our control cases. In addition to recognizing these variations, use of the dissecting microscope avoids more serious errors in histological interpretation.

In the post-gastrectomy patients, the villous types encountered were, with one exception, similar to those seen in the controls, but leaf-shaped villi and ridge formation were more frequent, being found in $70 \%$ of the group. The possible significance of these findings and their relationship to the occurrence of malabsorption are discussed.

One patient showed a flat mucosa similar to that found in some patients with idiopathic steatorrhoea. The significance of this is discussed and the importance of recognizing such cases is stressed.

We wish to thank Professor A. Currie and Professor A. G. Macgregor for advice during the preparation of this paper. We also thank Miss E. Simpson and Mr. David Noble for technical assistance.

\section{REFERENCES}

Ashworth, C. T., and Chears, W. C., Jr. (1962). Follow-up of intestinal biopsy in nontropical sprue after gluten-free diet and remission. Fed. Proc., 21, 880-890.

Badenoch, J., Evans, J. R., Richards, W. C. D., and Witts, L. J. (1955). Megaloblastic anaemia following partial gastrectomy and gastro-enterostomy. Brit. J. Haemat., 1, 339-344.

Baird, I. M., and Oleesky, S. (1957). Osteomalacia following gastric surgery. Gastroenterology, 33, 284-292.

tomy. Quart. J. Med., 26, 393-400.

Booth, C. C., Stewart, J. S., Holmes, R., and Brackenbury, W. (1962). Dissecting microscope appearances of intestinal mucosa. In Intestinal Biopsy, edited by G. E. W. Wolstenholme and M. P. Cameron, pp. 2-23. (Ciba Foundation Study Group No. 14.) Churchill, London. 
Brandborg, L. L., Rubin, G. E., and Quinton, W. E. (1959). A multipurpose instrument for suction biopsy of the oesophagus, stomach, small bowel, and colon. Gastroenterology, 37, $1-16$.

Butterworth, C. E. Jr., and Perez-Santiago, E. (1958). Jejunal biopsies in sprue. Ann. intern. Med., 48, 8-29.

Callender, S. T., Witts, L. J., Allison, P. R., and Gunning, A. (1961). Some metabolic and haematological effects of oesophagojejunostomy with by-pass of the stomach. Gut, 2, 150-157.

Cameron, D. G., Bensley, E. H., English, A., and Wood, P. (1955). Steatorrhoea following operations on the gastro-intestinal tract. Canad. med. Ass. J., 73, 819-821.

Clark, C. G., Crooks, J., Dawson, A. A., and Mitchell, P. E. G. (1964). Disordered calcium metabolism after polya partial gastrectomy. Lancet, 1, 734-738.

Cooke, W. T., Peeney, A. L. P., and Hawkins, C. F. (1953). Symptoms, signs, and diagnostic features of idiopathic steatorrhoea. Quart. J. Med., 22, 59-77.

Crosby, W. H., and Kugler, H. W. (1957). Intraluminal biopsy of the small intestine: the intestinal biopsy capsule. Amer.J. dig. Dis., 2, 236-241.

Deller, D. J. (1962). Megaloblastic and transitional megaloblastic anaemia following partial gastrectomy. Study of 27 cases. Aust. Ann. Med., 11, 235-249.

-_, Richards, W. C. D., and Witts, L. J. (1962). Changes in the blood after partial gastrectomy with special reference to vitamin $\mathbf{B}_{12}$. II. The cause of the fall in serum vitamin $\mathbf{B}_{12}$. Quart.J. Med., 31, 89-102.

Ellman, P., and Irwin, D. B. (1959). Osteomalacia following gastrectomy. Postgrad. med. J., 35, 358-361.

Fone, D. J., Meynell, M. J., Harris, E. L., Cooke, W. T., Brewer, D. B., and Cox, E. V. (1960). Jejunal biopsy in adult coeliac disease and allied disorders. Lancet, 1, 933-938.

Fowler, D. I., and Cooke, W. T. (1960). Diagnostic significance of d-xylose excretion test. Gut, 1, 67-70.

Girdwood, R. H. (1962). Malabsorptive disorders: investigations and their bearing on treatment. (John Matheson Shaw Lecture.) In Symposium. The Study of Normal and Disordered Function of the Small Intestine. Royal College of Physicians of Edinburgh Publication, No. 17, pp. 7-50. R.C.P., Edinburgh.

, Delamore, I. W., and Wynn Williams, A. (1961). Jejunal biopsy in malabsorptive disorders of the adult. Brit. med. J., 1, 319-323.

Harvald, B., Krogsgaard, A. R., and Lous, P. (1962). Calcium deficiency following partial gastrectomy. Acta med. scand., 172, 497-503.

Hillemand, P., Mialaret, J., and Boutelier, D. (1960). A propos d'une ostéomalacie après gastrectomie partielle avec anastomose gastro-jéjunale: transformation par rétablissement du circuit duodénal. Arch. Mal. Appar. dig., 49, 489-500.
Holmes, R., Hourihane, D. O'B., and Booth, C. C. (1961 a). Dissectingmicroscope appearances of jejunal biopsy specimens from patients with "Idiopathic Steatorrhoea". Lancet, 1, 81-83. p (1961b). The mucosa of the small intestine. Postgrad. med. $J ., 37,717-724$.

Jones, C. T., Cox, E. V., Cooke, W. T., Williams, J. A., Meynell, M. J. and Stammers, F. A. R. (1962). Peptic ulceration. Som haematological and metabolic consequences of gastric surgery. Lancet, 2, 425-428.

Joske, R. A., and Blackwell, J. B. (1959). Alimentary histology in the malabsorption syndrome following partial gastrectomy. Lancet 2, 379-382.

Kamer, J. H. van de, Huinink, H. ten B., and Weyers, H. A. (1949). Rapid method for the determination of fat in feces. J. biol. Chem., 177, 347-355.

Lees, F., and Grandjean, L. C. (1958). The gastric and jejunal mucosae in healthy patients with partial gastrectomy. Arch. intern. Med. 101, 943-951.

Melick, R. A., and Benson, J. A. Jr. (1959). Osteomalacia following partial gastrectomy. New Engl. J. Med., 260, 976-978.

Mitchell, P. E. G., Dawson, A., Clark, C. G., and Crooks, J. C. (1964) To be published.

Paulley, J. W. (1954). Observations on the aetiology of idiopathic steatorrhoea; jejunal and lymph-node biopsies. Brit. med. J., 2, 1318-1321.

_- Fairweather, F. A., and Leeming, A. (1957). Post-gastrectomy steatorrhoea and patchy jejunal atrophy. Lancet, 1, 406-407.

Paulson, M., and Harvey, J. C. (1954). Hematological alterations after total gastrectomy: evolutionary sequences over a decade. J. Amer. med. Ass., 156, 1556-1560.

Pyrah, L. N., and Smith, I. B. (1956). Osteomalacia following gastrectomy, Lancet, 1, 935-937.

Ralston, M., Wood, I. J., and Hughes, A. (1960). Small-bowe biopsy with the suction biopsy tube. Aust. Ann. Med., 9 , 103-110.

Rubin, C. E., Brandborg, L. L., Phelps, P. C., and Taylor, H. C. Jr (1960). Studies of celiac disease. I. The apparent identical and specific nature of the duodenal and proximal jejunal lesion in celiac disease and idiopathic sprue. Gastroenterology, 38, 28-49.

Schacter, D., and Rosen, S. M. (1959). Active transport of $\mathrm{Ca}^{45}$ by the small intestine and its dependence on Vitamin D. Amer. J. Physiol., 196, 357-362.

Scott, G. B., Williams, M. J., and Clark, C. G. (1963). Unpublished observations.

Shiner, M., and Doniach, I. (1960). Histopathologic studies in steatorrhea. Gastroenterology, 38, 419-440.

Verzár, F., and McDougall, E. J. (1936). Absorption from the Intestine. Longmans, London.

Yardley, J. H., Bayless, T. M., Norton, J. H., and Hendrix, T. R. (1962). Celiac disease. A study of the jejunal epithelium before and after a gluten-free diet. New Engl. J. Med., 267, 1173-1179. 